Studia nad Autorytaryzmem i Totalitaryzmem 43, nr 1

Wrocław 2021

https://doi.org/10.19195/2300-7249.43.1.20

AGNIESZKA MALICKA

ORCID: 0000-0003-1722-7300

Uniwersytet Wrocławski

agnieszka.malicka@uwr.edu.pl

\title{
Prawa podstawowe w systemie konstytucyjnym Niemieckiej Republiki Demokratycznej
}

Słowa kluczowe: prawa podstawowe, konstytucja, socjalizm, prawa jednostki, prawa kolektywne, demokracja ludowa.

\author{
FUNDAMENTAL RIGHTS IN THE CONSTITUTIONAL SYSTEM \\ OF THE GERMAN DEMOCRATIC REPUBLIC
}

\begin{abstract}
The German Democratic Republic, as a state of real socialism, guaranteed its citizens, in addition to classical individual fundamental rights, also collective rights. Their use was made conditional, depending on the fulfilment of obligations specified in the Constitution. In the GDR, there were no independent bodies and mechanisms to protect the rights of citizens. Constitutional system of fundamental rights was primarily serving the good of the community and the development of a modern socialist state.
\end{abstract}

Keywords: fundamental rights, constitution, socialism, individual rights, collective rights, people's democracy.

Trzydzieści lat po zjednoczeniu Niemiec oczywiste jest, że Niemiecka Republika Demokratyczna była państwem tylko z nazwy demokratycznym. Z perspektywy czasu panujący w tym kraju system polityczny i prawny, oparty na marksistowsko-leninowskiej ideologii, określa się jednoznacznie jako faktycznie sprzeczny z jakimikolwiek zasadami demokracji czy demokratycznego państwa prawa. NRD była państwem totalitarnym i reżimowym. W czasie jej dość krótkiego, zaledwie 
czterdziestoletniego istnienia, obywatele NRD, podlegający przez lata partyjnej indoktrynacji, często żyli w złudnym przekonaniu, że system zagwarantowanych im konstytucyjnie praw obywatelskich jest idealny, prawdziwie demokratyczny i postępowy, w odróżnieniu od burżuazyjnych i tworzących jedynie iluzję demokracji ustrojów państw zachodnich, w tym w szczególności Republiki Federalnej Nie$\mathrm{miec}^{1}$. Zmiany polityczne zachodzące w Europie Wschodniej pod koniec lat osiemdziesiątych XX wieku uświadomiły obywatelom NRD, że socjalistyczny system gwarantowanych konstytucyjnie praw podstawowych w rzeczywistości stanowił jedynie nic nieznaczącą dla jednostki deklarację organów władzy.

\section{Utworzenie Niemieckiej Republiki Demokratycznej i geneza jej Konstytucji}

W swojej czterdziestoletniej historii NRD zasadniczo miała aż trzy konstytucje. Pierwsza przyjęta została w 1949 roku wraz z utworzeniem nowego państwa i określana była po prostu jako Konstytucja NRD, druga — nazywana konstytucją socjalistyczną — weszła w życie w 1968 roku, a w 1974 roku wprowadzono tak zwaną zrewidowaną konstytucję. Konstytucja z 1968 roku, w brzmieniu z 1974 roku, obowiązywała, po dokonaniu niezbędnych zmian w 1989 roku $^{2}$, aż do zjednoczenia Niemiec w 1990 roku.

Geneza pierwszej konstytucji NRD sięga roku 1946, kiedy kierownictwo Socjalistycznej Partii Jedności Niemiec (Sozialistische Einheitspartei Deutschlands - SED) ogłosiło projekt „,praw zasadniczych narodu niemieckiego”. Był on przedmiotem dyskusji między innymi Niemieckich Kongresów Ludowych (Deutscher Volkskongress) ${ }^{3}$, w ramach których podejmowano starania o utrzymanie jedności Niemiec. Przedmiotem obrad pierwszego Kongresu Ludowego było przede wszystkim przygotowanie traktatu pokojowego i utworzenie wspólnego demokratycznego rządu niemieckiego. Efektem drugiego Kongresu Ludowego było referendum dotyczące jedności Niemiec, które przeprowadzone zo-

${ }^{1}$ Zob. między innymi literaturę dotyczącą Konstytucji NRD z lat sześćdziesiątych i siedemdziesiątych XX wieku, na przykład W. Büchner-Uhder, Konstytucja Niemieckiej Republiki Demokratycznej, „Ruch Prawniczy, Ekonomiczny i Socjologiczny” 1969, nr 2, https://repozytorium.amu. edu.pl/handle/10593/18860 (dostęp: 12.06.2021); Konstytucja Niemieckiej Republiki Demokratycznej, przeł. A. Burda, Wrocław-Warszawa 1971, s. 5.

2 Zmiany polegały przede wszystkim na usunięciu socjalistycznego charakteru Konstytucji.

3 Niemiecki Kongres Ludowy był gremium powołanym z inicjatywy SED, a jego pierwsze posiedzenie miało miejsce 6 grudnia 1947 roku. Jego uczestnikami byli przedstawiciele partii i organizacji antyfaszystowskich z radzieckiej strefy okupacyjnej oraz delegaci z zachodnich stref okupacyjnych. Głównym celem Kongresów Ludowych było ustanowienie jednolitego rządu niemieckiego. Łącznie odbyły się trzy zebrania tego organu — drugie miało miejsce 17 i 18 marca 1948 roku, w setną rocznicę Wiosny Ludów. 
stało w terminie od 23 maja do 13 czerwca 1948 roku $^{4}$ Ponadto wybrana została pierwsza Rada Ludowa (Deutscher Volksrat) ${ }^{5}$, powołano też komisję konstytucyjną (Verfassungsausschuss) ${ }^{6}$, której zadaniem było opracowanie konstytucji Niemieckiej Republiki Demokratycznej. Na trzecim Kongresie Ludowym, który odbył się w dniach 29 i 30 maja 1949 roku, przyjęty ${ }^{7}$ został opracowany przez komisję konstytucyjną projekt Konstytucji, ponadto wybrano drugą Radę Ludową. W odpowiedzi na utworzenie z trzech zachodnich stref okupacyjnych Republiki Federalnej Niemiec ${ }^{8}$ opisane powyżej działania zostały ostatecznie zwieńczone proklamowaniem 7 października 1949 roku na terytorium radzieckiej strefy okupacyjnej oddzielnego państwa niemieckiego - Niemieckiej Republiki Demokratycznej (Deutsche Demokratische Republik - DDR).

Niemiecka Republika Demokratyczna przyjęła konstytucyjną zasadę jednolitości władzy państwowej, a przewidziane w jej Konstytucji podstawy ustroju gospodarczego, oparte na własności państwowej, otworzyły drogę do stopniowego, pełnego przekształcenia nowo powstałego państwa w państwo socjalistyczne, działające na podstawie doktryny marksistowsko-leninowskiej ${ }^{9}$.

\section{Prawa podstawowe w Konstytucji NRD z 7 października 1949 roku}

Konstytucja z 1949 roku $^{10}$ liczyła 144 artykuły i składała się ze wstępu oraz trzech części, w których kolejno uregulowane zostały — w części A: podstawy

${ }^{4}$ W referendum z ogólnej liczby 38 milionów Niemców uprawnionych do głosowania 15 milionów opowiedziało się za utrzymaniem jedności Niemiec.

5 Rada Ludowa liczyła 400 członków, z tego 100 z zachodnich stref okupacyjnych.

${ }^{6}$ Komisją Konstytucyjną kierował Otto Grothewohl - przyszły premier NRD.

7 Odnotowano jeden głos ,przeciw”.

823 maja 1949 roku w zachodnich strefach okupacyjnych, tak zwanej Trizonii, przyjęta została Ustawa Zasadnicza Republiki Federalnej Niemiec (Grundgesetz für die Bundesrepublik Deutschland), która weszła w życie dzień później, i tym samym utworzone zostało nowe państwo niemieckie, nieobejmujące swoimi granicami terytorium radzieckiej strefy okupacyjnej — Republika Federalna Niemiec (Bundesrepublik Deutschland). Zob. także W. Bleek, Die Geschichte der $D D R$, https:/www.bpb.de/geschichte/deutsche-einheit/deutsche-teilung-deutsche-einheit/43650/ ddr-geschichte?p=all (dostęp: 12.06.2021).

${ }^{9}$ Ustrój socjalistyczny NRD stopniowo ugruntowywany był przez kolejne zmiany Konstytucji i uchwalenie nowej w 1968 roku.

10 Verfassung der Deutschen Demokratischen Republik vom 7. Oktober 1949, GB1. 1949, I, S. 5, https://www.1000dokumente.de/index.html?c=dokument_de\&dokument=0232_ddr\&object $=$ translation\&l=de (dostęp: 12.06.2021). W Konstytucji z 1949 roku trzykrotnie wprowadzano zmiany dotyczące organów państwowych na podstawie odpowiednio ustaw zmieniających: Gesetz zur Ergänzung der Verfassung vom 26. September 1955 (GB1. I S. 653), Gesetz über die Auflösung der Länderkammer vom 8. Dezember 1958 (GBl. I S. 867) oraz Gesetz über die Bildung des Staatsrates vom 12. September 1960 (GB1. I S. 505). Ostatecznie jej obowiązywanie uchylone zostało przez uchwalenie i wejście w życie nowej Konstytucji z 6 kwietnia 1968 roku — Verfassung der DDR 
władzy państwowej, w części B: treść i granice władzy państwowej oraz w części C: struktura władzy państwowej. Nie była jeszcze typową konstytucją państwa socjalistycznego ${ }^{11}$, a jej twórcy wzorowali się na rozwiązaniach przyjętych w Konstytucji weimarskiej ${ }^{12}$. W art. 1 nowe państwo niemieckie zostało określone jako niepodzielna republika demokratyczna ${ }^{13}$. W szczególności podkreślono w niej znaczenie takich wartości jak wolność, prawa człowieka czy sprawiedliwość społeczna ${ }^{14}$.

Prawa podstawowe zawarte zostały w części B. Ustrojodawca w art. 6-49 uregulował katalog praw i wolności o charakterze osobistym, uzupełniając go nowym $^{15}$, obszernym katalogiem kolektywnych praw socjalnych. Istotnym elementem tych regulacji były jednoczesne ograniczenia i zastrzeżenia ustawowe, towarzyszące poszczególnym konstytucyjnie gwarantowanym prawom i wolnościom. Zwykle w przepisach tych znajdowały się sformułowania typu: „o ile ustawa nie stanowi inaczej” lub „władza państwowa może na podstawie powszechnie obowiązujących ustaw niniejsze prawo ograniczyć lub ich pozbawić"16.

Katalog praw podstawowych rozpoczynały postanowienia o równości wszystkich obywateli wobec prawa (art. 6) ${ }^{17}$ oraz równouprawnieniu kobiet i mężczyzn (art. 7). W dość ogólny sposób zagwarantowane zostały wolność osobista, nienaruszalność mieszkania, zachowanie tajemnicy korespondencji, prawo swobodnego osiedlania się w wybranym miejscu ${ }^{18}$ (art. 8) oraz prawo do swobodnego wra-

vom 6. April 1968 (GBl. I. S. 199). Tłumaczenie na język polski zob. Konstytucja Niemieckiej Republiki Demokratycznej, Berlin-Dresden 1968.

11 Konstytucja z 1949 roku zawierała jeszcze postanowienia charakterystyczne dla zachodnich systemów demokratycznych. Należały do nich między innymi katalog praw podstawowych czy regulacje dotyczące wyborów do parlamentu. W praktyce przepisy te nie były jednak realizowane, a władze państwowe regularnie dopuszczały się łamania postanowień konstytucyjnych. W przypadku wyborów parlamentarnych stało się to już w 1950 roku, pogwałcono wtedy podstawowe zasady prawa wyborczego. Zob. między innymi Vor 70 Jahren: Erste Verfassung für die $D D R$, https://www.bpb.de/politik/hintergrund-aktuell/291996/vor-70-jahren-erste-verfassung-fuerdie-ddr (dostęp: 12.06.2021).

12 Konstytucja Rzeszy Niemieckiej z 11 sierpnia 1919 roku - Die Verfassung des Deutschen Reichs/Weimarer Reichsverfassung, http://www.documentarchiv.de/wr/wrv.html (dostęp: 7.06.2021). Konstytucja weimarska stanowiła podstawę dla ustroju niemieckiej demokracji parlamentarnej w latach 1918-1933.

13 Deutschland ist eine unteilbare demokratische Republik.

14 Zob. tekst preambuły do Konstytucji z 7 października 1949 roku, a także: G.J. Glaeßner, Staatsvertsändnis, Verfassungs- und Rechtsgeschichte der DDR 1949-1989, „Zeitschrift für Parlamentsfragen" 21, 1990, nr 1, s. 103 n.

15 W odróżnieniu od klasycznego podziału praw i wolności obywatelskich.

16 Teoretycznie zasada ograniczenia praw podstawowych w drodze powszechnie obowiązujących ustaw jest regułą obowiązującą w państwach demokratycznych. Jednak analizując te przepisy z perspektywy czasu, nie można mieć żadnych wątpliwości, jaki cel miały owe zastrzeżenia ustawowe w Konstytucji NRD.

17 Art. 6 Konstytucji NRD odgrywał szczególną rolę, o której w dalszej części opracowania.

18 Zasadniczo wybór dotyczyć mógł wyłącznie terytorium Niemieckiej Republiki Demokratycznej. 
żania poglądów i organizowania $\mathrm{w}$ tym celu pokojowych zgromadzeń, a także zakaz cenzurowania prasy (art. 9). W art. 10 umieszczono zakaz ekstradycji obywateli NRD oraz ich prawo do emigracji. Konstytucja zapewniała także prawa dla mniejszości językowych, w szczególności możliwość używania swojego języka w szkolnictwie oraz w administracji i sądownictwie (art.11) ${ }^{19}$. W kolejnych przepisach (art. 12-14) znalazła się gwarancja prawa do zrzeszania się obywateli w związkach i stowarzyszeniach, jednakże pod warunkiem, że ich tworzenie nie narusza przepisów prawa karnego. Zakładane przez obywateli organizacje były uprawnione do kształtowania i uczestniczenia w życiu publicznym, w tym do wystawiania swoich kandydatów w wyborach przedstawicielstw narodu w gminach, powiatach i landach. Przepisy te miały umożliwiać także tworzenie związków zawodowych oraz prawo do strajku. Część Konstytucji omawiającą kolektywne prawa socjalne otwierały postanowienia gwarantujące prawo do pracy i zapewnienie niezbędnych środków do życia oraz konstytucyjną ochronę siły roboczej (art. 15). Kolejnymi gwarancjami w tej kategorii były: prawo do wypoczynku, urlopu i opieki społecznej opartej na systemie ubezpieczeń społecznych (art. 16), prawo do odpowiedniego wynagrodzenia za pracę oraz równego wynagrodzenia dla kobiet i mężczyzn za taką samą pracę, a także prawo pracowników do współdecydowania o sprawach zakładu pracy w ramach przynależności do związków zawodowych i rad zakładowych. Ponadto Konstytucja miała zapewniać szczególną ochronę kobiet oraz młodzieży w ramach stosunku pracy (art. 17 i 18). W kolejnej części (art. 19-29) zawarte zostały przepisy dotyczące ustroju gospodarczego NRD, który miał gwarantować wszystkim dobrobyt i pokrycie wszelkich potrzeb życiowych. Konstytucja miała dawać jednostce wolność działalności gospodarczej oraz rozwój prywatnej inicjatywy przy wsparciu i rozszerzaniu społecznej samopomocy i na podstawie odpowiednich planów gospodarczych (art. 19-21).

Artykuły od 22 do 29 regulowały prawo własności oraz zasady nacjonaliza$\mathrm{cji}^{20}$. Te przepisy potraktowane zostały przez ustawodawcę w sposób najbardziej radykalny poprzez wskazanie wprost w nich licznych ograniczeń. $Z$ art. 22 wynikała wprawdzie gwarancja prawa własności i dziedziczenia, jednak przy uwzględnieniu obowiązku społecznego jednostki wobec ogółu wspólnoty oraz prawa państwa do udziału w spadku. Co więcej, w Konstytucji przewidziano także prawo do wywłaszczenia, wprawdzie za odpowiednim odszkodowaniem i z możliwością odwołania się do sądu, jednak i tu pojawiło się zastrzeżenie ustawowe (art. 23 i 27). Ponieważ w praktyce zawsze chodziło o wywłaszczenia w celu uspołecznienia i w związku z wymogami interesu ogólnego, oznaczało to de facto nacjo-

19 Przepisy te dotyczyły zamieszkujących na terytorium NRD Serbołużyczan — słowiańskiej mniejszości narodowej.

${ }^{20} \mathrm{Na}$ temat form własności w NRD zob. między innymi O.W. Jakobs, Allgemeine Rechtsfragen des Volkseigentums in der ,,DDR“, „JuristenZeitung” 22, 1967, nr 2, s. 46-51, https://www.jstor. org/stable/20808065 (dostęp: 20.06.2021); oraz L. Janicki, Ustrój polityczny NRD, [w:] Niemiecka Republika Demokratyczna. Praca zbiorowa, red. B. Gruchman, B. Wiewióra, Poznań 1963, s. 208 n. 
nalizację bez odszkodowania. Zgodnie z przepisami Konstytucji własność społeczna stanowiła podwalinę dla socjalistycznej gospodarki ${ }^{21} \mathrm{i}$ jako taka podlegała szczególnej ochronie ze strony państwa ${ }^{22}$. Na podstawie kolejnych postanowień konstytucyjnych wykluczone zostały wszelkie formy własności kapitalistycznej, takie jak monopole, kartele, syndykaty, koncerny i trusty (art. 24), a istniejące spółki prywatne ${ }^{23}$ stanowiły jedynie formę przejściową w drodze do całkowitego uspołecznienia.

Konstytucja gwarantowała ponadto każdemu obywatelowi prawo do mieszkania (art. 26). W części III katalogu praw podstawowych (art. 30-33) zawarto regulacje, których celem była ochrona macierzyństwa i rodziny, a w artykułach od 34 do 40 unormowano kwestie związane $\mathrm{z}$ wychowaniem i wykształceniem. W związku ze szczególną ochroną macierzyństwa matkom przyznano konstytucyjne prawo do uzyskania odpowiedniej opieki socjalnej ze strony państwa i jego instytucji (art. 32) 24 . Jednocześnie ujednolicony został status prawny dzieci pochodzących z małżeństwa i tych pozamałżeńskich (art. 33). Konstytucja gwarantowała przede wszystkim wychowanie dzieci przez odpowiednie instytucje publiczne, w których zatrudniani byli wykwalifikowani wychowawcy i nauczyciele ${ }^{25}$. Wychowanie dzieci i młodzieży odbywało się w duchu Konstytucji i miało przyczynić się do ukształtowania samodzielnie myślących i odpowiedzialnie działających ludzi, którzy będą w stanie dopasować się do życia wspólnoty (art. 37). Rola rodziców w wychowaniu dzieci realizowana była w ramach działalności rad rodziców. Jednocześnie Konstytucja gwarantowała wszystkim dzieciom, niezależnie od ich statusu materialnego, prawo dostępu do bezpłatnego szkolnictwa oraz w razie potrzeby wsparcie ze strony państwa na wszystkich szczeblach kształcenia, a także prawo wyboru zawodu (art. 38 i 39). Ponadto Konstytucja gwarantowała wolność sztuki, nauki i nauczania, pod warunkiem realizacji tych wolności w duchu Konstytucji (art. 34).

21 Tak zwana własność państwowa lub narodowa uznawana była za najwyższą formę własności społecznej, a przedsiębiorstwa własności ludowej (Volkseigene Betriebe - VEB) funkcjonowały zarówno w przemyśle, jak i w rolnictwie. Sukcesywnie przejmowane indywidualne gospodarstwa rolne były łączone i przekształcane w rolnicze spółdzielnie produkcyjne (landwirtschaftliche Produktionsgenossenschaften - LPG). Teoretycznie należąca do rolnika ziemia pozostawała nadal jego własnością, jednak spółdzielni przysługiwało pełne prawo jej użytkowania.

22 Ochronie służyły między innymi zaostrzone przepisy prawa karnego w przypadku przestępstw przeciwko mieniu społecznemu.

23 Udziały w takich spółkach przejmowane były przez państwo, a w ważnych sprawach spółki decyzje podejmowane były w porozumieniu z zakładowymi związkami zawodowymi. Zob. L. Janicki, op. cit., s. 210.

24 Państwo zobowiązało się do stworzenia odpowiednej infrastruktury gwarantującej ochronę matek i dzieci.

${ }^{25}$ W NRD funkcjonował odpowiedni państwowy system kształcenia wyższego dla przyszłych nauczycieli i wychowawców. 
Ostatnia, V część katalogu praw podstawowych (art. 41-48) zawierała gwarancje wolności sumienia i wyznania. Zgodnie $z$ artykułem 41 wszyscy obywatele mogli korzystać z pełnej swobody wyznania i sumienia, a państwo zobowiązane zostało do ochrony praktyk religijnych, jednak wszelkiego rodzaju działalność religijna nie mogła pozostawać w sprzeczności z celami konstytucyjnymi i partyjno-politycznymi. Przynależność religijna była kwestią swobodnej decyzji obywatela, nie podlegała ujawnianiu i miała pozostawać bez jakiegokolwiek wpływu na możliwość korzystania z praw obywatelskich, w tym także z prawa do służby publicznej. Zasadniczo w NRD obowiązywała zasada rozdziału państwa i kościoła. Kościołom i związkom wyznaniowym pozostawiono swobodę w regulowaniu swoich spraw wewnętrznych, ograniczoną ,jedynie" obowiązującymi przepisami ustawowymi ${ }^{26}$.

Katalog praw podstawowych zamykało postanowienie artykułu 49, dotyczące skuteczności zawartych w nim praw. Zgodnie z nim wprowadzanie ograniczeń lub konkretyzowanie poszczególnych praw w drodze zwykłego ustawodawstwa nie mogło naruszać istoty tego prawa.

Przedstawione powyżej prawa podstawowe można by uznać za demokratyczne, postępowe i służące dobru społeczeństwa, gdyby nie fakt możliwości wprowadzania ograniczeń ustawowych przy ich realizacji. Uwagę zwraca także tytuł nadany tej części Konstytucji — „treść i granice władzy państwowej”, z którego raczej trudno wywnioskować, że przedmiotem jej regulacji są prawa i wolności obywatela. Utożsamienie praw podstawowych z granicami władzy państwowej i jednocześnie przyjęcie tak zwanego zastrzeżenia ustawowego w tych regulacjach spowodowały, że prawom tym można przypisać jedynie deklaratoryjny charakter.

${ }^{26} \mathrm{Na}$ temat stosunków państwa i Kościoła w NRD zob. między innymi H. Zander, Kirche in der DDR, „Aus Politik und Zeitgeschichte” 4-5, 1988, s. 29-38, http://perso.unifr.ch/helmut. zander/wp-content/uploads/2015/09/Zander-Zur-Situation-der-katholischen-Kirche-in-der-DDR. pdf (dostęp: 5.06.2021). W praktyce państwo dążyło do ograniczenia wpływów Kościoła na życie obywateli poprzez stosowanie represji wobec wiernych. Zob. między innymi E. Neubert, Kościót i opozycja, „Raporty Fundacji Konrada Adenauera” 2011, nr 18, s. 5 n., https://www.kas.de/c/document_library/get_file?uuid=964e97ff-87c9-13c7-6608-2d97a837bf94\&groupId=252038 (dostęp: 15.06.2021). W NRD zmodyfikowana i upolityczniona została znana w Niemczech od 1852 roku uroczystość laickiego wejścia uczniów niewierzących w dorosłość w wieku 14 lat. W NRD Jugednweihe odbywało się na zakończenie 8. klasy, a więc u kresu nauki w szkole podstawowej, i było poprzedzone dziesięciogodzinnym przygotowaniem z zakresu wiedzy o socjalizmie. Udział w tej uroczystości był obowiązkowy dla każdego ucznia. Jej główną częścią było przemówienie partyjnego aktywisty na temat świadomego udziału młodzieży w budowaniu socjalizmu i złożenie przez nią uroczystego ślubowania, że będzie ona budować socjalizm i go bronić. Następnie każdy uczestnik otrzymywał pamiątkę książkową (publikacje o tematyce socjalistycznej wskazane przez władze państwowe). Jugednweihe nadal jest celebrowane w Niemczech, jednak obecnie, zgodnie z pierwotną ideą, nie ma charakteru politycznego i jest świecką uroczystością dla młodzieży nienależącej do żadnych związków wyznaniowych. 


\section{Prawa podstawowe w Konstytucji NRD z 1968 roku}

Przemiany społeczno-polityczne w NRD i stopniowa zmiana świadomości obywateli, będąca efektem ciągłej indoktrynacji, uzasadniały konieczność zmian w Konstytucji. Na wniosek I sekretarza Komitetu Centralnego SED, Waltera U1brichta, opracowany został projekt nowej Konstytucji. Została ona przyjęta przez Izbę Ludową 26 marca 1968 roku $^{27}$, a następnie, dla podkreślenia jej demokratycznego charakteru, poddana pod głosowanie w ogólnokrajowym referendum, przeprowadzonym 6 kwietnia tego samego roku ${ }^{28}$, zaś jej wejście w życie nastąpiło 9 kwietnia 1968 roku. Tym samym ugruntowany i umocniony został w NRD socjalistyczny ustrój wzorowany na systemie i Konstytucji Związku Socjalistycznych Republik Radzieckich z 1936 roku.

Nowa, socjalistyczna konstytucja narodu niemieckiego ${ }^{29}$ zastąpiła Konstytucję z 1949 roku, która była tak zwaną konstytucją okresu przejściowego. Liczyła 108 artykułów i podzielona została na pięć części, regulujących kolejno następujące zagadnienia: podstawy socjalistycznego ustroju społecznego i państwowego (art. 1-18), obywatele i wspólnoty społeczeństwa socjalistycznego (art. 19-46), organizacja i system kierownictwa państwowego (art. 47-85), socjalistyczna praworządność i wymiar sprawiedliwości (art. 86-106) i postanowienia końcowe (art. 107-108). Zgodnie z artykułem 1 „NRD jest państwem socjalistycznym narodu niemieckiego. Jest ona polityczną organizacją mas pracujących miast i wsi, które wspólnymi siłami, pod przewodnictwem klasy robotniczej i jej partii

27 GB1. I S. 199, http://www.documentarchiv.de/ddr/verfddr.html (dostęp: 12.06.2021), thumaczenie na język polski: Konstytucja NRD, Warszawa 1975.

28 W referendum uczestniczyło $98 \%$ uprawnionych, a 94,5\% z nich opowiedziało się za przyjęciem nowej konstytucji. Zob. DDR: Die Verfassung von 1968, https://www.bpb.de/geschichte/zeitgeschichte/deutschland-chronik/131554/6-april-1968 (dostęp: 12.06.2021). Referendum towarzyszyła tajna akcja „Optymizm” (Aktion „Optimismus”), przeprowadzona na rozkaz nr 8/68 ministra bezpieczeństwa państwowego Ericha Mielke, która trwała od godziny 17.0028 marca 1968 roku do godziny 17.007 kwietnia 1968. Celem tej operacji było monitorowanie nastrojów społecznych, w szczególnosci obserwowanie, czy nie ujawnią się przeciwnicy nowej konstytucji. Było to jedyne w historii NRD referendum ogólnokrajowe, w którym obywatele mieli faktyczny wybór pomiędzy „tak” i „nie”. W konstytucji z 1968 roku przepisy o referendum zostały uchylone. Więcej na temat referendum konstytucyjnego zob. informacje na stronie internetowej Pełnomocnika Federalnego do spraw Materiałów Państwowej Służby Bezpieczeństwa NRD (Der Bundesbeauftragte für die Stasi-Unterlagen): https://www.bstu.bund.de/DE/Presse (dostęp: 15.06.2021).

${ }^{29}$ Konstytucja z 1968 roku określana była w ten sposób dla podkreślenia faktu, że służyła przede wszystkim realizacji socjalizmu w NRD. Określenie to używane było także w samej treści Konstytucji. Socjalistyczna konstytucja oznaczała między innymi, że w swoich założeniach oparta była na marksistowsko-leninowskiej doktrynie państwa, w której podstawą ustroju gospodarczo-społecznego była socjalistyczna własność, a system organów państwowych ukształtowany był zgodnie z obowiązującym socjalistycznym modelem. W końcu termin ten oznaczał także, że system praw i wolności obywatelskich odpowiadał specyficznym socjalistycznym założeniom. Zob. między innymi A. Burda, op. cit., s. 7. 
marksistowsko-leninowskiej, budują socjalizm" ${ }^{30}$. Zgodnie z art. 4 władza socjalistyczna służyć miała dobru narodu, zapewniać mu życie w pokoju, umożliwiać planową poprawę stopy życiowej i chronić jego prawa, gwarantować swobodny rozwój człowieka, chronić jego godność i zapewniać zawarte w Konstytucji pra$\mathrm{wa}^{31}$. I temu właśnie urzeczywistnianiu socjalizmu służyły także gwarantowane w Konstytucji prawa podstawowe, uregulowane w rozdziale II.

Konstytucja z 1968 roku gwarantowała w zasadzie te same prawa podstawowe co jej poprzedniczka sprzed niemal dwudziestu lat. Zabrakło wśród nich jednak prawa do oporu, zakazu cenzury prasy, prawa do emigracji oraz prawa do strajku ${ }^{32}$. Nowym rozwiązaniem było także połączenie praw podstawowych z obowiązkami obywatela, na co wskazywał już sam tytuł rozdziału II. Katalog praw podstawowych został zatem sformułowany w taki sposób, że korzystanie z zawartych w nim praw zostało uzależnione od wypełnienia konkretnych obowiązków. Przyjęcie tego rozwiązania przez ustrojodawcę stanowiło de facto wprowadzenie daleko idących ograniczeń praw podstawowych ${ }^{33}$. Tym samym w socjalistycznym systemie prawnym NRD nie spełniały one już takiej samej funkcji jak prawa podstawowe gwarantowane w systemach prawnych liberalnych państw demokratycznych, takich jak chociażby Republika Federalna Niemiec ${ }^{34}$. Nie zapewniały zatem obywatelom zakresu wolności bez ingerencji władz państwowych, służyły przede wszystkim budowaniu nowej, socjalistycznej świadomości obywateli i utożsamianiu ich interesów z interesami państwa jako socjalistycznej wspólnoty. Prawa podstawowe realizowane były w duchu socjalistycznych zasad i celów nowej Konstytucji. Zapisane w Konstytucji z 1968 roku prawa podstawowe zasadniczo miały charakter praw kolektywnych, a nie indywidualnych.

W katalogu praw podstawowych znalazły się zatem: poszanowanie i ochrona godności i wolności osobistej (art. 19) czy zasada niedyskryminacji i równości wszystkich obywateli wobec prawa (art. 20). Jednym z ważniejszych praw podstawowych było prawo do współdecydowania w kwestiach politycznych, gospodarczych, społecznych i kulturalnych w myśl konstytucyjnej zasady: „Współpracuj,

${ }^{30}$ Zob. Konstytucja Niemieckiej Republiki Demokratycznej, Berlin-Dresden 1968, s. 9.

31 Ibidem, s.10.

32 H. Mahnke, Menschen- und Grundrechte in beiden Teilen Deutschlands, „Vereinte Nationen: German Review on the United Nations" 17, 1969, nr 1, s. 5

33 Ograniczenia zawarte były nie tylko bezpośrednio w katalogu praw podstawowych. Także nowy kodeks karny, przyjęty 12 stycznia 1968 roku przez Izbę Ludową, a obowiązujący od 1 czerwca tego samego roku, zawierał rozbudowany system drakońskich kar za naruszenia zagrażające porządkowi publicznemu NRD. Przy tym przepisy te sformułowane były w sposób pozwalający na ich rozszerzającą interpretację przez organy ścigania. Zatem nawet najdrobniejsza krytyka systemu politycznego lub funkcjonariuszy władzy państwowej podlegała karze. Zob. między innymi P. Borowsky, Die DDR in den sechziger Jahren, „Informationen zur Politischen Bildung” 2002, z. 258, https://www.bpb.de/izpb/10105/die-ddr-in-den-sechziger-jahren?p=all (dostęp: 15.06.2021).

${ }^{34}$ Zob. między innymi opracowanie służb naukowych Bundestagu: Fragen zur DDR - Verfassung im Vergleich mit dem Grundgesetz, s. 6, https://www.bundestag.de/resource/blob/422898/ cd5058f62cb62fd679b49ff115b5fc51/wd-3-151-09-pdf-data.pdf (dostęp: 16.06.2021). 
współplanuj, współrządź!"35. W tym przypadku ustawodawca także wprost wskazał na obowiązek każdego obywatela do urzeczywistniania tego prawa (art. 21) ${ }^{36}$. W kolejnych postanowieniach znalazły się: aktywne prawo wyborcze przysługujące od ukończenia 18. roku życia (art. 22), prawo azylu (art. 23), prawo do pracy i wolność wyboru miejsca pracy zgodnie z wymaganiami społecznymi i kwalifikacjami osobistymi (art. 24), prawo do kształcenia (art. 25 i 26) i kolejno w art. 27-29: wolność wyrażania poglądów, zgromadzeń oraz wolność zrzeszania się. Art. 30 gwarantował nietykalność osobistą oraz wolność obywateli. Jednocześnie wolność ta mogła być ograniczana ze względu na popełnienie czynów karalnych, ale także z powodu konieczności leczenia lub innego ustawowego uzasadnienia. Było to na tyle niedokładnie i niejasno sformułowane postanowienie, że w rzeczywistości odpowiednie służby państwowe mogły dokonywać ich swobodnej interpretacji. Kolejne regulacje zapewniały tajemnicę korespondencji i komunikacji (art. 31), swobodę przemieszczania się w granicach terytorium państwa (art. 32), zakaz ekstradycji (art. 33), prawo do wolnego czasu, wypoczynku i płatnego urlopu, a także prawo do ochrony zdrowia i zdolności do pracy oraz opieki społecznej (art. 34-36), prawo do mieszkania i jego nienaruszalności (art. 37). W art. 38 znalazły się gwarancje dotyczące ochrony małżeństwa, rodziny i macierzyństwa, a także wspierania rodzin wielodzietnych. Podobnie jak w konstytucji z 1949 roku podkreślono szczególną rolę instytucji państwowych w wychowywaniu „dzielnych i wszechstronnie wykształconych ludzi na świadomych obywateli swego państwa”. Tak więc indoktrynacja obywateli NRD rozpoczynała się już w okresie wczesnego dzieciństwa, co faktycznie umożliwiło socjalistycznej władzy ukształtowanie zupełnie nowego obywatela o socjalistycznej świadomości. Katalog praw podstawowych zamykały gwarancja wolności wyznania (art. 39) oraz zapewnienie Serbołużyczanom jako mniejszości narodowej prawa do używania swojego języka i pielęgnowania swojej kultury (art. 40).

\section{Prawa podstawowe w zrewidowanej Konstytucji NRD z 1974 roku}

Dwudziestopięciolecie istnienia państwa stało się dla Ericha Honeckera ${ }^{37}$ okazją do wprowadzenia zmian ustrojowych, których celem było przede wszystkim jeszcze silniejsze podkreślenie odrębności NRD od RFN i zaznaczenie, że wschod-

${ }^{35}$ Arbeite mit, plane mit, regiere mit!

36 Art. 21 ust. 3: „Urzeczywistnianie tego prawa do współdecydowania i współkształtowania stanowi zarazem wysokie zobowiązanie moralne każdego obywatela".

37 Erich Honecker został I sekretarzem Komitetu Centralnego SED w maju 1971 roku i od razu podjął działania mające na celu zmianę Konstytucji w celu „podniesienia jakości centralnego państwowego kierownictwa i planowania”. Zob. L. Janicki, Najnowsze przemiany ustrojowe w Niemieckiej Republice Demokratycznej, https://repozytorium.amu.edu.pl/bitstream/ 
nia część Niemiec stała się rozwiniętym państwem socjalistycznym ${ }^{38}$. W znowelizowanej Konstytucji z 7 października 1974 roku $^{39}$ na nowo zdefiniowany został suweren - tym razem byli to robotnicy i chłopi (pracujący miast i wsi) ${ }^{40}$. Formalna i faktyczna zależność NRD od Związku Radzieckiego jako gwarancja dalszego rozwoju socjalizmu także znalazła swoje potwierdzenie bezpośrednio w art. $6^{41}$. Zmiany w Konstytucji dotyczyły przede wszystkim organizacji i funkcjonowania organów władzy. W wersji z 1974 roku liczyła ona 106 artykułów przy zachowaniu podziału na pięć części, noszących takie same tytuły jak we wcześniejszej wersji konstytucji ${ }^{42}$.

Prawa podstawowe oraz podstawowe obowiązki obywatela były zatem nadal przedmiotem regulacji części II, artykułów 19-40. Jedyne modyfikacje w tej części Konstytucji dotyczyły biernego prawa wyborczego - w art. 22 ust. 2 granica wieku została obniżona do 18. roku życia. Ponadto w art. 20 ust. 3 zmieniona została kolejność słów „planowanie i kierowanie” (Planung und Leitung) na „kierowanie i planowanie" (Leitung und Planung) ${ }^{43}$.

\section{Przepisy karne w Konstytucjach NRD}

Specyficznym dla systemu NRD rozwiązaniem było wprowadzenie do Konstytucji przepisów karnych, które znajdowały bezpośrednie zastosowanie na podstawie art. 6. Zgodnie z postanowieniami końcowymi ${ }^{44}$ Konstytucji jej przepisy stanowiły prawo bezpośrednio obowiązujące. Należy w tym miejscu zaznaczyć, że przedmiotem regulacji art. $6 \mathrm{w}$ Konstytucji z 1949 roku zasadniczo była gwarancja równości wszystkich obywateli wobec prawa. Regulacja ta została przeniesiona do art. 20 w kolejnych konstytucjach z 1968 i 1974 roku.

Zgodnie z art. 6 wszystkich trzech Konstytucji NRD przestępstwem były podżeganie do bojkotu wobec demokratycznych instytucji i organizacji, wszelkiego

10593/20464/1/005\%20LECH\%20JANICKI\%20RPEiS\%2037\%283\%29\%2C\%201975.pdf(dostęp: 16.06.2021).

38 Zob. preambułę Konstytucji z 1974 roku.

39 Konstytucja Niemieckiej Republiki Demokratycznej (Verfassung der Deutschen Demokratischen Republik), GBl. I., s. 432, http://www.verfassungen.de/ddr/verf68-i.htm (dostęp: 16.06.2021); tłumaczenie na język polski zob. Konstytucja NRD, Warszawa 1975.

40 Zob. art. 1: „Niemiecka Republika Demokratyczna jest socjalistycznym państwem robotników i chłopów".

41 Zob. art. 6 ust. 2 „Niemiecka Republika Demokratyczna jest na zawsze i nieodwracalnie sprzymierzona ze Związkiem Socjalistycznych Republik Radzieckich”.

42 Zob. w części dotyczącej Konstytucji z 1968 roku.

43 Zmiana ta dotyczyła także kilku innych postanowień niedotyczących bezpośrednio praw podstawowych. Hasło ,planuj i kieruj” było jednym z przewodnich haseł używanych w socjalistycznej konstytucji NRD.

44 Zob. art. 144 Konstytucji z 1949 roku, art. 107 Konstytucji z 1968 roku i art. 105 Konstytucji z 1974 roku. 
rodzaju propaganda militarystyczna i odwetowa, podżeganie do wojny oraz okazywanie nienawiści religijnej, rasowej i narodowej. Konstytucja określała jednak, inaczej niż tradycyjne ustawy karne, jedynie znamiona czynu, brakowało natomiast konkretnie określonego zagrożenia karą. To niedookreślenie stanowiło dla organów ścigania możliwość dokonywania swobodnej interpretacji zarówno w zakresie oceny konkretnego działania, jak również wymiaru kary. Ponieważ przestępstwa te traktowane były jako naruszenie demokratycznego porządku publicznego i zagrożenie dla socjalistycznego ustroju, zwykle orzekane były najsurowsze kary ${ }^{45}$. Dodatkową karą w myśl Konstytucji z 1949 roku było pozbawienie praw publicznych. Taki system karania wywoływał w społeczeństwie tzw. „efekt mrożący” i powodował zastraszanie nieposłusznych wobec systemu obywateli.

\section{Realizacja praw podstawowych w NRD}

Gdyby z zagwarantowanych w Konstytucjach NRD praw podstawowych wykreślić sformułowania o socjalistycznej ojczyźnie, socjalistycznej wspólnocie i urzeczywistnianiu socjalizmu, to ich katalog nie różniłby się zbytnio od praw podstawowych zawartych chociażby w Ustawie Zasadniczej Republiki Federalnej Niemiec. Co więcej, umieszczone w nich prawa o charakterze socjalnym można by uznać za rzeczywiście postępowe i nowoczesne w rozwijającym się państwie. Jednak głównym problemem przy realizacji praw podstawowych przez obywateli NRD były ich deklaratoryjny charakter oraz zasada zastrzeżeń ustawowych. Nie bez znaczenia było także odmienne od klasycznego, obowiązującego w zachodnich demokracjach, rozumienie tychże praw. W demokracji ludowej ich celem było przede wszystkim zagwarantowanie obywatelom ich współudziału w sprawowaniu władzy. Miały służyć dobru społeczności i tym samym przyczyniać się do budowy socjalizmu. Szczególną rolę odgrywały przy tym także kolektywne prawa podstawowe, $\mathrm{z}$ których korzystały socjalistyczne wspólnoty, takie jak rady zakładowe, związki zawodowe itp. Korzystanie z praw podstawowych w NRD każdorazowo uzależnione było od woli organów władzy socjalistycznej, która dzięki obowiązującej zasadzie jednolitości władzy państwowej mogła w dowolnym momencie ustanowić regulacje ograniczające prawa podstawowe. Zasada jednolitości władzy powodowała także brak jakichkolwiek niezależnych od rządzących organów czy instytucji, na przykład sądowniczych ${ }^{46}$ oraz odpowiednich

45 Zob. między innymi Ch. Kleßmann, Aufbau eines sozialistischen Staates, https://www. bpb.de/geschichte/deutsche-einheit/deutsche-teilung-deutsche-einheit/43701/der-aufbau-der-ddr (dostęp: 16.06.2021).

46 System sądownictwa w NRD był całkowicie podporządkowany władzy państwowej sprawowanej przez partyjnych funkcjonariuszy. Już sam fakt dopuszczania do studiów prawniczych wyłącznie dzieci członków partii oraz konieczność przynależności do niej jako warunek rozpoczęcia kariery sędziowskiej świadczy o wypaczeniu całego systemu wymiaru sprawiedliwości w NRD. 
mechanizmów, które gwarantowałyby obywatelom ochronę ich konstytucyjnych praw i wolności ${ }^{47}$. System sądownictwa jako taki był zagwarantowany konstytucyjnie, jednakże zgodnie z art. 5 ust. 1 Konstytucji NRD z 1968 roku, według którego obywatele NRD sprawowali władzę polityczną poprzez demokratycznie wybrane przedstawicielstwa ludowe, pozostałe organy władzy wykonawczej, administracji państwowej oraz władzy sądowniczej wykonywały jedynie zlecone im zadania. Zauważyć należy, że przedstawicielstwa ludowe korzystały także z prawa kontroli sądów. Zatem konstytucje NRD gwarantowały obywatelom prawo do $\mathrm{sądu}^{48}$, a oprócz tego istniała przewidziana w przepisach konstytucyjnych gwarancja społecznej ochrony praw obywateli ${ }^{49}$. W tym celu powoływane były na wzór rozwiązań radzieckich sądy społeczne ( gesellschaftliche Gerichte). Szczegóły ich działalności uregulowane były w odrębnej ustawie ${ }^{50}$. Ponadto na podstawie odrębnych dekretów wydawanych przez Radę Państwa ${ }^{51}$ działały komisje odwoławcze przy terenowych organach przedstawicielskich. Zgodnie z nimi każdemu obywatelowi NRD przysługiwało prawo do składania skarg do przedstawicielstw ludowych, posłów, radnych i innych organów państwowych, przedsiębiorstw i instytucji socjalistycznych ${ }^{52}$. Zgodnie z obowiązującą w NRD doktryną państwa socjalistycznego ochrona praw obywateli mogła odbywać się także poprzez ich aktywny współudział w zarządzaniu państwem. Zasadniczo istniał zatem dość rozbudowany system organów ochrony praw obywateli, jednakże każdy ze wskazanych organów był albo wprost zależny od władzy państwowej, albo obsadzo-

Zob. między innymi H. Mahnke, op. cit., s. 5; oraz opracowanie służb naukowych Bundestagu: Fragen zur DDR - Verfassung im Vergleich mit dem Grundgesetz, s. 12, https://www.bundestag. de/resource/blob/422898/cd5058f62cb62fd679b49ff115b5fc51/wd-3-151-09-pdf-data.pdf (dostęp: 16.06.2021).

47 Zob. między innymi G. Geuther, M. Metzner, Grundrechte in anderen Verfassungen, https://www.bpb.de/izpb/254039/grundrechte-in-anderen-verfassungen (dostęp: 16.06.2021)

48 Zob. na przykład art. 101 i 102 Konstytucji z 1968 roku.

49 W Konstytucji z 1968 roku gwarancja ta wynikała z art. 103.

50 Ustawa o sądach społecznych NRD z 11 czerwca 1968 roku (Gesetz über die gesellschaftlichen Gerichte der Deutschen Demokratischen Republik vom 11. Juni 1968), uchylona następnie ustawą o sądach społecznych z 12 marca 1982 roku (Gesetz über die gesellschaftlichen Gerichte der DDR vom 12. März 1982, GB1. I. S 269). Podstawę prawną dla utworzenia sądów społecznych stanowił art. 92 Konstytucji NRD z 1968 roku. Więcej o sądach społecznych zob. A. Elser, Gesellschaftsgerichte in der DDR, [w:] Kleines kriminologisches Wörterbuch. 2. völlig neubearbeitetet und erweiterte Auflage, red. G. Kaiser, Heidelberg 1985, s. 140-145; E. Buchholz, Gesellschaftliche Gerichte und sozialistischer Staat, „ARSP: Archiv für Rechts- und Sozialphilosophie” 75, 1989, nr 1, s. 72-81.

51 Dekret Rady Państwa NRD z 27 lutego 1961 roku w sprawie skarg obywateli i ich załatwiania przez organy państwa (Erlaß des Staatsrates der Deutschen Demokratischen Republik über die Eingaben der Bürger und die Bearbeitung durch die Staatsorgane vom 27. Februar 1961 geändert durch Erlaß des Staatsrates vom 18. Februar 1966, GBl. I, s. 69). Akt ten został uchylony przez kolejny Dekret Rady Państwa NRD z 1969 roku (Erlaß des Staatsrates der DDR über die Bearbeitung der Eingaben der Bürger vom 20. November 1969, GBl. I. s. 239).

52 Szerzej o tym sposobie rozstrzygania sporów zob. W. Büchner-Uhder, op. cit., s. 8 n. 
ny aktywnymi działaczami partyjnymi, którzy w swoich decyzjach kierowali się przede wszystkim dobrem socjalistycznego państwa i dobrem wspólnym. W rzeczywistości obywatel, którego prawa zostały naruszone, miał jedynie iluzoryczną możliwość uzyskania ochrony prawnej. Działalność organów państwa w NRD, w tym także tych powołanych do ochrony praw obywateli, nie podlegała żadnej kontroli, na przykład ze strony sądu konstytucyjnego, ponieważ takowy nie istniał. Obywatele nie mogli liczyć także na wsparcie organizacji międzynarodowych w ochronie swoich praw podstawowych. Niemiecka Republika Demokratyczna uczestniczyła wprawdzie na początku lat siedemdziesiątych XX wieku w Konferencji Bezpieczeństwa i Współpracy w Europie i nawet podpisała w 1975 roku Akt Końcowy z Helsinek, na podstawie którego jego sygnatariusze zobowiązywali się do przestrzegania praw człowieka, jednak nigdy nie wprowadziła w życie jego postanowień. Protesty wobec tych działań kończyły się represjami i ukaraniem protestujących mimo sprzeciwu organizacji międzynarodowych. Taki stan utrzymywał się praktycznie do końca istnienia NRD. Ostatnie dziesięć lat jej istnienia to okres ożywionej działalności opozycji ${ }^{53}$. Pomimo prowadzonej przez lata indoktrynacji i izolacji obywateli NRD ${ }^{54}$ od liberalnych państw Europy Zachodniej część obywateli była świadoma, że żyją w ,państwie bezprawia” (Unrechtssaat) ${ }^{55}$ i mimo grożących im represji nie godzili się oni na taki stan rzeczy. Jednak do masowych wystąpień coraz bardziej niezadowolonych z warunków życia w socjalistycznym państwie obywateli doszło dopiero jesienią 1989 roku $^{56}$. Wtedy do pogłębiającego się kryzysu gospodarczego, politycznego i ideologicznego doszły jeszcze zmiany polityczne w państwach bloku wschodniego ${ }^{57} .9$ listopada 1989 roku upadł mur berliński ${ }^{58}$, a rok później, 3 października 1990 roku, nastąpiło zjednoczenie Niemiec. Obowiązująca w ponownie zjednoczonym państwie Ustawa Zasadnicza Re-

53 Opozycja polityczna w NRD rozwinęła swoją działalność pod wpływem wydarzeń w Polsce — przede wszystkim powstania Solidarności w 1980 roku.

54 Takiej izolacji służył między innymi zbudowany w 1961 roku mur berliński, odgradzający Berlin Wschodni od Zachodniego.

$55 \mathrm{~W}$ literaturze dotyczącej okresu istnienia NRD posługiwano się pojęciem Unrechtsstaat, które na język polski można przetłumaczyć jako „państwo bezprawia” lub „państwo nieprawości”. Pojęcie to odnosi się do systemu politycznego przeciwnego zasadom państwa prawa (Rechtsstaat). Debaty polityczne na ten temat miały miejsce między innymi w 2009 i 2019 roku przy okazji obchodów kolejnych rocznic zjednoczenia Niemiec. Zob. E. Holtmann, Die DDR - ein Unrechtsstaat?, https://www.bpb.de/geschichte/deutsche-einheit/lange-wege-der-deutschen-einheit/47560/unrechtsstaat (dostęp: 16.06.2021); opracowanie służb naukowych Niemieckiego Bundestagu: Rechtsstaat und Unrechtsstaat: Begriffsdefinition, Begriffsgenese, aktuelle politische Debatten und Umfragen, https://www.bundestag.de/resource/blob/575580/dddea7babdd1088b2ele85b97f408ce2/WD-1-02218-pdf-data.pdf (dostęp: 16.06.2021).

56 W tak zwanych „poniedziałkowych demonstracjach” protestujący domagali się przeprowadzenia wolnych wyborów, prawa do zgromadzeń i rozliczenia odpowiedzialnych za dotychczasowy system. O upadku NRD zob. W. Bleek, op.cit.

57 Zob. I.S. Kowalczuk, Das Ende der DDR 1989/90. Von der Revolution über den Mauerfall zur Einheit, „Aus Politik und Zeitgeschichte” 2019, nr 35-37, s. 4 n.

58 Upadek muru berlińskiego był procesem trwającym od maja 1989 roku. 
publiki Federalnej Niemiec i oparta na zasadzie demokratycznego państwa prawa interpretacja zawartych w niej praw podstawowych pozwoliły wielu obywatelom byłej NRD po raz pierwszy zrozumieć sens i istotę systemu ochrony jednostki przed nadmierną ingerencją państwa.

\section{Bibliografia}

Bleek W., Die Geschichte der DDR, https://www.bpb.de/geschichte/deutsche-einheit/deutsche-teilung-deutsche-einheit $/ 43650 /$ ddr-geschichte? $\mathrm{p}=$ all.

Borowsky P., Die DDR in den sechziger Jahren, „Informationen zur Politischen Bildung” 2002, z. 258.

Buchholz E., Gesellschaftliche Gerichte und sozialistischer Staat, „ARSP: Archiv für Rechts- und Sozialphilosophie" 75, 1989, nr 1.

Büchner-Uhder W., Konstytucja Niemieckiej Republiki Demokratycznej, „Ruch Prawniczy, Ekonomiczny i Socjologiczny" 1969, nr 2.

Elser A., Gesellschaftsgerichte in der DDR, [w:] Kleines kriminologisches Wörterbuch. 2. völlig neubearbeitetet und erweiterte Auflage, red. G. Kaiser, Heidelberg 1985.

Fragen zur DDR - Verfassung im Vergleich mit dem Grundgesetz, https://www.bundestag.de/resource/blob/422898/cd5058f62cb62fd679b49ff115b5fc51/wd-3-151-09-pdf-data.pdf.

Geuther G., Metzner M., Grundrechte in anderen Verfassungen, https://www.bpb.de/izpb/254039/ grundrechte-in-anderen-verfassungen.

Glaeßner G.J., Staatsvertsändnis, Verfassungs- und Rechtsgeschichte der DDR 1949-1989, [w:] „Zeitschrift für Parlamentsfragen” 21, 1990, nr 1.

Holtmann E., Die DDR - ein Unrechtsstaat?, https:/www.bpb.de/geschichte/deutsche-einheit/ lange-wege-der-deutschen-einheit/47560/unrechtsstaat.

Jakobs O.W., Allgemeine Rechtsfragen des Volkseigentums in der „DDR“, „JuristenZeitung” 22, 1967, nr 2.

Janicki L. Ustrój polityczny NRD, [w:] Niemiecka Republika Demokratyczna. Praca zbiorowa, red. B. Gruchman, B. Wiewióra, Poznań 1963.

Janicki L., Najnowsze przemiany ustrojowe w Niemieckiej Republice Demokratycznej, https://repozytorium.amu.edu.pl/bitstream/10593/20464/1/005\%20LECH\%20JANICKI\%20RPEiS\%20 $37 \% 283 \% 29 \% 2 \mathrm{C} \% 201975$.pdf.

Kleßmann Ch., Aufbau eines sozialistischen Staates, https://www.bpb.de/geschichte/deutsche-einheit/deutsche-teilung-deutsche-einheit/43701/der-aufbau-der-ddr.

Konstytucja Niemieckiej Republiki Demokratycznej, Berlin-Dresden 1968.

Konstytucja Niemieckiej Republiki Demokratycznej, przeł. A. Burda, Wrocław-Warszawa 1971.

Konstytucja NRD, Warszawa 1975.

Kowalczuk I.S., Das Ende der DDR 1989/90. Von der Revolution über den Mauerfall zur Einheit, „Aus Politik und Zeitgeschichte” 2019, nr 35-37.

Mahnke H., Menschen- und Grundrechte in beiden Teilen Deutschlands, „Vereinte Nationen: German Review on the United Nations" 17, 1969, nr 1.

Neubert E., Kościót i opozycja, „Raporty Fundacji Konrada Adenauera” 2011, nr 18.

Rechtsstaat und Unrechtsstaat: Begriffsdefinition, Begriffsgenese, aktuelle politische Debatten und Umfragen, https://www.bundestag.de/resource/blob/575580/dddea7babdd1088b2ele85b97f408ce2/WD-1-022-18-pdf-data.pdf.

Vor 70 Jahren: Erste Verfassung für die DDR, https://www.bpb.de/politik/hintergrund-aktuell/291996/vor-70-jahren-erste-verfassung-fuer-die-ddr.

Zander H., Kirche in der DDR, „Aus Politik und Zeitgeschichte” 4-5, 1988.

Studia nad Autorytaryzmem i Totalitaryzmem 43, nr 1, 2021

(C) for this edition by CNS 